\title{
"Archetypal Forms" in Modern Sculpture. The Image of Reclining Figure: From Maillol to Moore, and so On
}

\section{A. O. Kotlomanov}

St. Petersburg Stieglitz State Academy of Art and Design,

13, Solyanoy line, St. Petersburg, 191028, Russian Federation

For citation: Kotlomanov, Alexander. “Archetypal Forms' in Modern Sculpture. The Image of Reclining Figure: From Maillol to Moore, and so On". Vestnik of Saint Petersburg University. Arts 9, no. 3 (2019): 558-576. https://doi.org/10.21638/spbu15.2019.307

On the basis of selected examples from the history of the sculpture of the first half and middle of the $20^{\text {th }}$ century, a range of issues related to the concepts of "symbolic form", "ideal" and "archetype" is analyzed. In the center of consideration is the image of the reclining figure in the works of Aristide Maillol and Henry Moore. Accepting the general statement that such sculptures embody the harmony of statics and dynamics, the author is keener to explore the historical patterns of the selection of a symbolic form in the category of a monument. The significance of the reclining figure is proved by separate historical examples related, in particular, to the work of Michelangelo, with classicism and its derivatives, the concept of the ideal form and the theory of architectonics. The theme of the ambiguity of the classical ideal, its fate in the $20^{\text {th }}$ century, and its dependence on political / ideological ideas is also emphasized. In the sculptural concept of Maillol, the qualities of picturesque, corporeality, and monumentality stand out. In the description of Moore's creativity, the reclining figure - "archetypal form" (term of Herbert Read) - is considered from the standpoint of identifying qualities in it that allowed the sculptor to realize it in a wide range of interpretations of form and content. Moore's creativity issues include the relationship between sculpture and space, the interpretation of the statue's silhouette, the revealing of the "landscape" and "pictorial" qualities in it, as well as the extensive theme of addressing classical heritage. The monumental characteristics of Moore's reclining figures are analyzed; examples of their interpretation (including the artist himself) and critics are considered. The idea of a symbolic figure in the balance of a figurative and abstract form is adopted as an alternative to the monumental traditional, with emphasis on individual qualities.

Keywords: Aristide Maillol, Henry Moore, form, archetype, figure, sculpture, art, monument.

In the situation of the art of the first half - mid $-20^{\text {th }}$ century, the phenomenon of a conservative reaction was of great importance. This trend has spread in various areas of the visual arts, and it is especially clearly pronounced in sculpture. In the genre of sculpture that is related to monumentality. For a long period of its history, sculpture existed in the synthesis system, where the basic element was the architecture. Accordingly, architectural principles for many centuries have been the universal dimension of sculpture. This historical fact formed the concept of architectonics by the $20^{\text {th }}$ century, one of the main creators of which was Adolf von Hildebrand [1;2]. This concept, although based on universal principles, is not indisputable, since it is based on speculative statements. However, it is impossible not to recognize its influence on the modus of sculpture, which is associated with the concepts

(c) Санкт-Петербургский государственный университет, 2019 
of classic and ideal. In the traditional format of sculpture, the concept of architectonics remains important today, although, again, it is vulnerable to criticism.

Ideality as a central concept of classicism has similar quality characteristics. The concept of the ideal is also a lot of architectural; it is a component of a kind of architectural philosophy, which, among other things, recognizes the objectivity of the architecture, the model for other types of art. For example, the famous concept of ancient art - the Kanon of Polykleitos - is both an expression of ideality and architectonics. The system of proportions is affirmed in architecture by a system of interconnections, which are blurred in sculpture and painting. The idea of the Order - a universal unit - in architecture is based on the harmonic interrelation of form and design. Ideality expressed in classical architectural forms is striking in its resilience, and this phenomenal resilience of ancient buildings is akin to the quality of monumentality. So architecture outside of any theme, plot, itself can express the idea of eternity, the idea of a monument.

In a system where architecture occupies a dominant position, other forms of art should play by its rules. And if in this case painting can play the role of an animating factor, then the sculpture becomes almost an architectural element that enhances the sense of tectonics of the building. And if we recognize the architecture as a literal embodiment of monumental qualities, then sculpture in this situation will emphasize these qualities. It becomes a symbolic form, the meaning of which goes to the architectural or monumental level, not directly related to the theme that is directly expressed in sculpture. Perhaps this pattern contributed to the fact that throughout the history of art in sculpture developed similar forms, although their direct meaning, the subject-matter could be distinguished depending on the cultural situation. This can be seen in such types of statues as a standing, seated and reclining figure. The latter type of figurative image in this context seems to be most interesting due to the simultaneous embodiment of the qualities of statics and dynamics, rest and movement.

If you give historical examples of such an image, it is obvious that one of his best incarnations is associated with the work of Michelangelo; these are the figures of the time of day in the famous Medici Chapel. This is one of the best expressions of the synthesis of sculpture and architecture, and the case of Michelangelo is unique in that his synthesis has the opposite nature - rather, architecture follows the principles of sculpture. Although this does not negate the fact that the sculptures themselves embody the architectural qualities, or the qualities of architectonics. The ideal embodiment of these qualities in the sculpture of classicism is presented in the works of Antonio Canova. Moreover, which is probably characteristic, he embodied various themes or subjects in figures of similar type.

And - on the art scene appears Aristide Maillol.

\section{Symbolic Figure: Aristide Maillol}

Aristide Maillol repelled by the two principles - that is the nature and the classics. The emphasis on natural origin was a common place in the conceptualization of art from the middle of the nineteenth century, when Gustave Courbet launched a manifesto of realism. Maillol correlated this principle with life itself, that is, he strengthened those qualities of realism that spoke of following nature, if understood in terms of landscape space. In this regard, he was certainly an innovator, not worse than those who are now called modernists. On the other hand, the achievements of Maillol are turned to the ideal, and in this respect he can be considered a representative of the conservative movement, that is, an anti-modernist. 


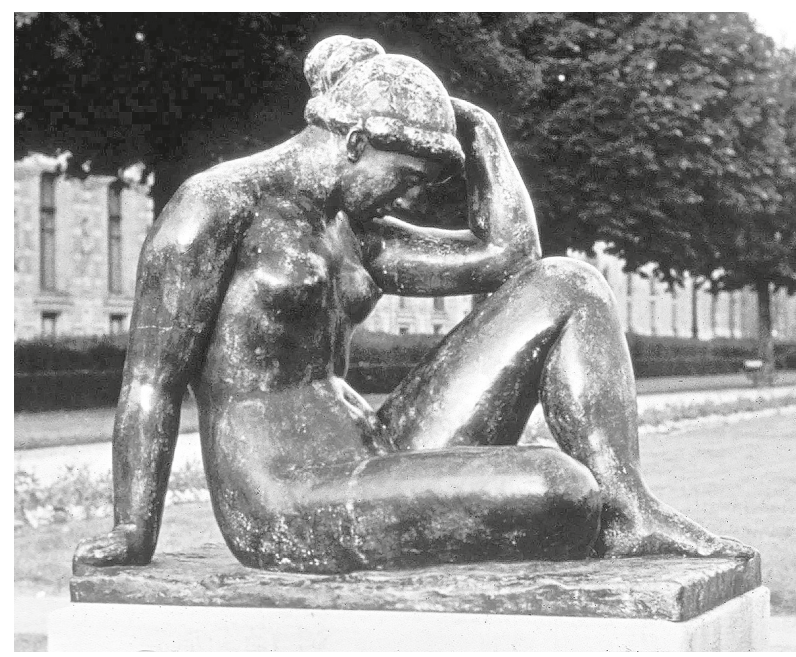

Fig. 1. Aristide Maillol. The Mediterranean. 1902-1905. Jardin des Tuileries, Paris

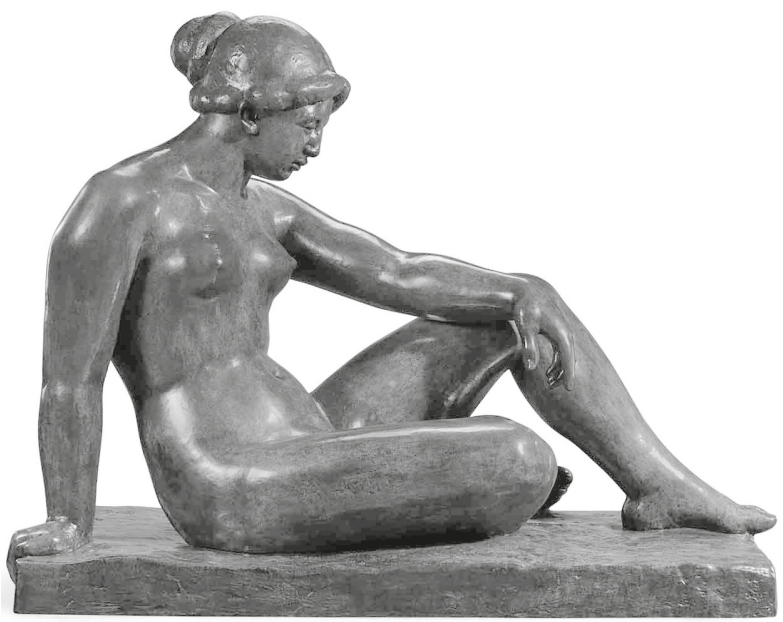

Fig. 2. Aristide Maillol. The Mediterranean. 1900-1902. Private collection

The activities of this outstanding sculptor had specific qualities that did not quite fit into the framework of typical professional ideas about sculpture. He was rather the author of the image, and this applied to its virtual side, and not to those moments that concern the direct work with the material. That is, he was much less concerned with the problems of texture, tactility, in general, all that is connected with the work with the surface of the work. Maillol perceived the sculpture as a three-dimensional embodiment of the symbolic image. At the same time, his searches were intuitive, it resembled the experiments of Symbolist artists, and do not forget that she started as a painter.

These qualities of his sculpture greatly contributed to the improvement of its "monumental potential". Here is a very typical case with one of his most famous sculptures, known as La Méditerranée [The Mediterranean] (fig. 1,2): 


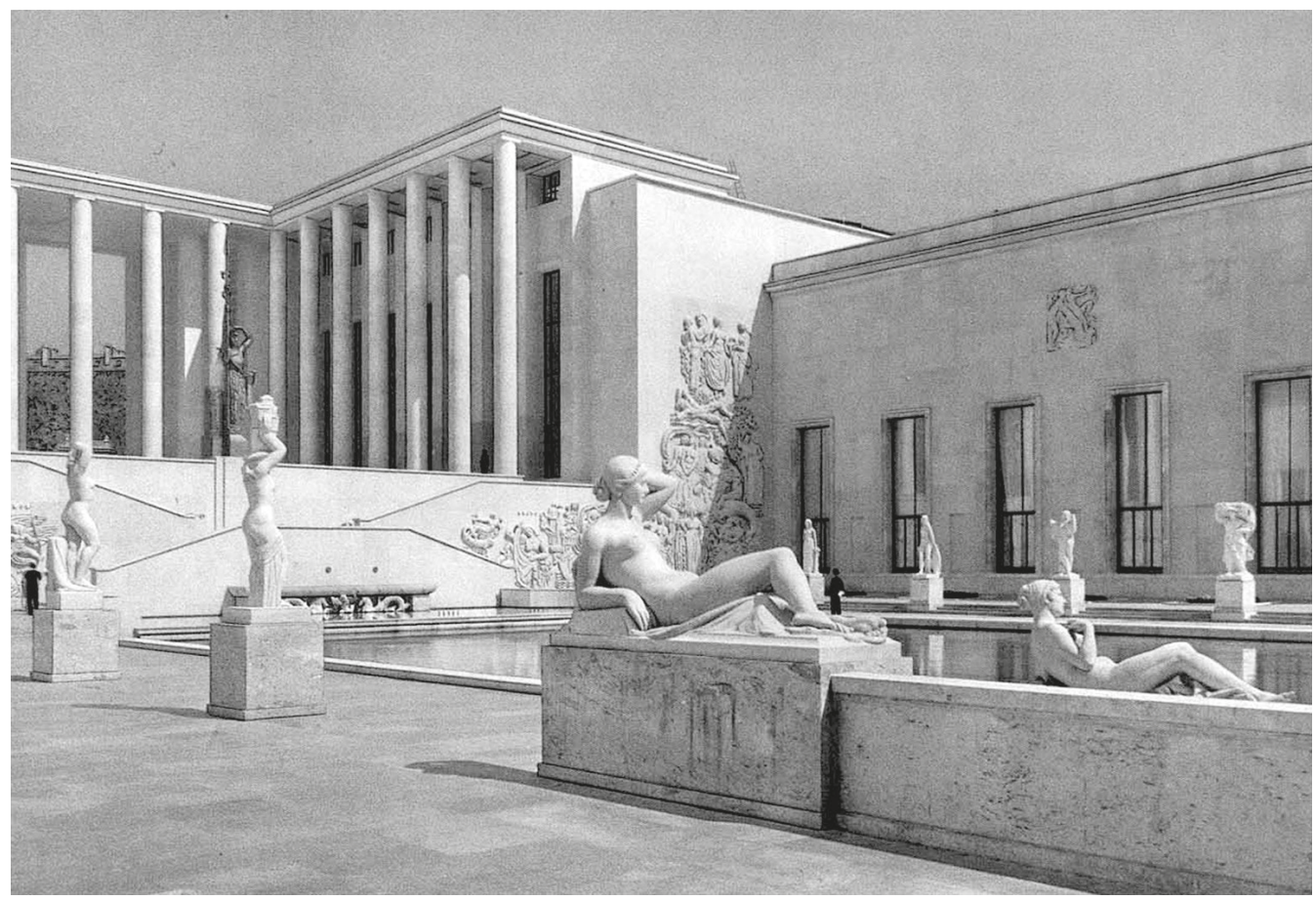

Fig. 3. Palais de Tokyo. Exposition Internationale des Arts et Techniques dans la Vie Moderne, Paris. 1937. Reclining figure at the center - 'Nymph' by Léon-Ernest Drivier

"The work that launched Maillol at the 1905 Salon d'Automne (and which Matisse helped to cast), simply titled "Woman", was received with warmth and erudition by a wide variety of writers, and studied by other artists who embraced the classical context $<\ldots>$ His supporters almost all defined Maillol in terms of a French Mediterraneanism which they saw as entirely instinctive, and in no way affected or learned. Nevertheless, "Woman" was repeatedly retitled, first becoming known as "Latin Thought" and then as "The Mediterranean" [3, p. 222].

Penelope Curtis notes that it was generally characteristic of European art:

"The nationalistic interest in invoking the classical plenitude began before the First World War, though it became more urgent, and for different reasons, thereafter. Auguste Renoir's late work offered a vision of a golden age which, combined with his status and longevity (comparable to Rodin's), seemed almost eternal. Renoir began to make sculptures with the help of Richard Guino, who had been recommended by Maillol as someone in keeping with the "Mediterranean spirit". Renoir's "Venus Victorious" (1914) is part of the increased interest in a French Mediterraneanism and presages the images of victory and peace provoked by the war" [3, p. 223].

The first half of the $20^{\text {th }}$ century was marked by turbulence of cultural processes, in which international exhibitions played a prominent role. For example, the expositions of 1937, which took place in Paris (fig. 3) and Munich, are widely known, where works of architecture and art were presented, the general meaning of which was reduced to the ideology of traditionalist revenge. While in these years the leading countries of the world, regardless of the vector of political ideology, once again came to understand the objective 
value of the classical heritage, the new round of classicism was closely interconnected with modernist tendencies. This paradoxical interrelation after a decade led to the final separation of two concepts - modernism and traditionalism (anti-modernism) and to the victory of the modernist idiom in artistic culture. What, besides the well-known political motives, was the cause of this triumph? The answer to this question cannot be unambiguous, but the ideology of renewal itself, the permanent revolution, the advantages of the new over the old, is seductive for a person striving for development. However, the myth of tradition also has its advantages. But — back to Maillol.

Maillol was the creator of a specific body aesthetic in which sensual and rational elements interacted. It was close to both Hildebrand's theory and to Boris Wipper, a prominent Soviet art theorist, in what he formulated as basic categories of sculpture:

"This nature of sculpture usually develops in close contact with architecture. The sculpture can be a support, participating in the architectural design (caryatids, atlantes, consoles, capitals), or to serve as decoration of the free fields, selected by the structure of the building $\langle\ldots\rangle$ But even in cases where there is no direct tectonic connection between sculpture and architecture, the sculpture is in a certain dependence on architecture: architecture determines the scale of the statue, its place, and to a large extent its lighting. But sculpture doesn't always have a subordinate role. There are cases when sculpture needs the support of architecture in order to unleash the full power of its energy, and then architecture submits to sculpture (Soviet pavilion at the Paris Exhibition and the Worker and Kolkhoz Woman by Mukhina). <..> ...Both the creation and the perception of the sculpture involve not only the visual organs, but also the tactile motor energy. The spectator as internally repeats the dynamic functions of the statue, with all its motor apparatus survives the positions and movements of the figure depicted - only then the stone and bronze from dead matter turn into a living image. It is clear that this process is possible only if there is an existing object - a person or an animal, a being with reason and will and with motor energy related to a person. It is not by chance that Maillol said to his students that when creating a new statue, he needed not so much an optical image as an internal, motor tension of the whole body that corresponds to a future statue" $[4$, p. $100-1]$.

Throughout his rather long creative life, Maillol turned to the same variants of the figure of a figure, so one can say that he had originally developed for himself something like a canon and subsequently followed him. This can be clearly seen from his standing and reclining figures. Since we are focusing on the subject of a Reclining Figure, we need to point out some significant examples of Maillol's work in this genre. Apparently, he attached to it the importance of monumentality, that is, he perceived this form from the standpoint of its architectural and at the same time symbolic qualities. Of course, the concept of an ideal is also included here, which is generally important for characterizing sculpture in the context of classicism and its renewal in the 20th century. So, one of the most characteristic examples can be considered the work of Maillol, called Monument à Cézanne, or L'Hommage à Cézanne (fig. 4, 5).

What do we see? We see a female figure, made in a style that can hardly be associated with Paul Cezanne. At the same time, the work of Maillol, of course, is filled with symbolic meaning, when we can build a certain plot line, following our knowledge of Cezanne. Cezanne was, on the one hand, a reformer of art, on the other - his discoveries were based on a deep study of the classical heritage. What Maillol ultimately presented is 


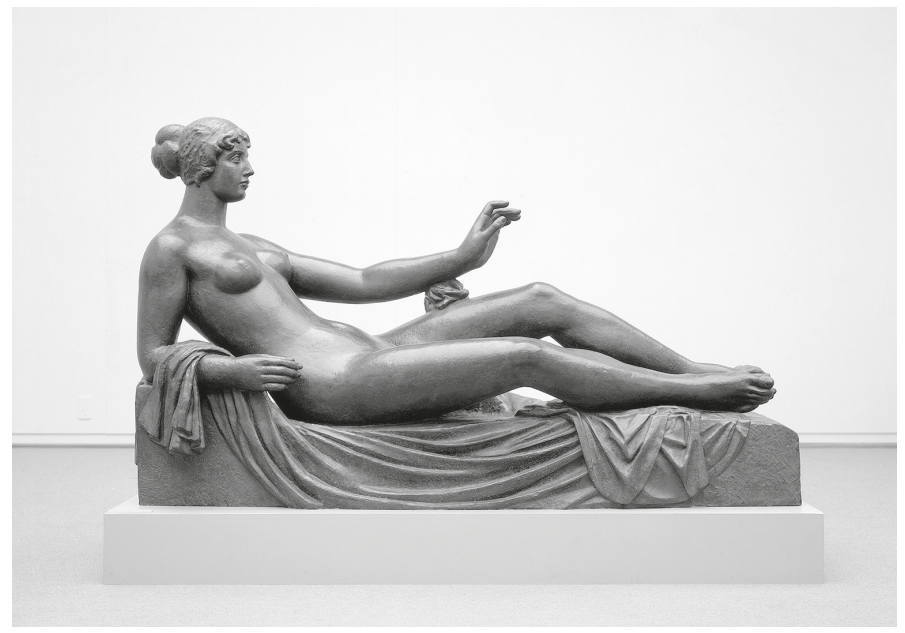

Fig. 4. Aristide Maillol. Monument à Cézanne (L'Hommage à Cézanne). 1907. Kunsthaus Zürich

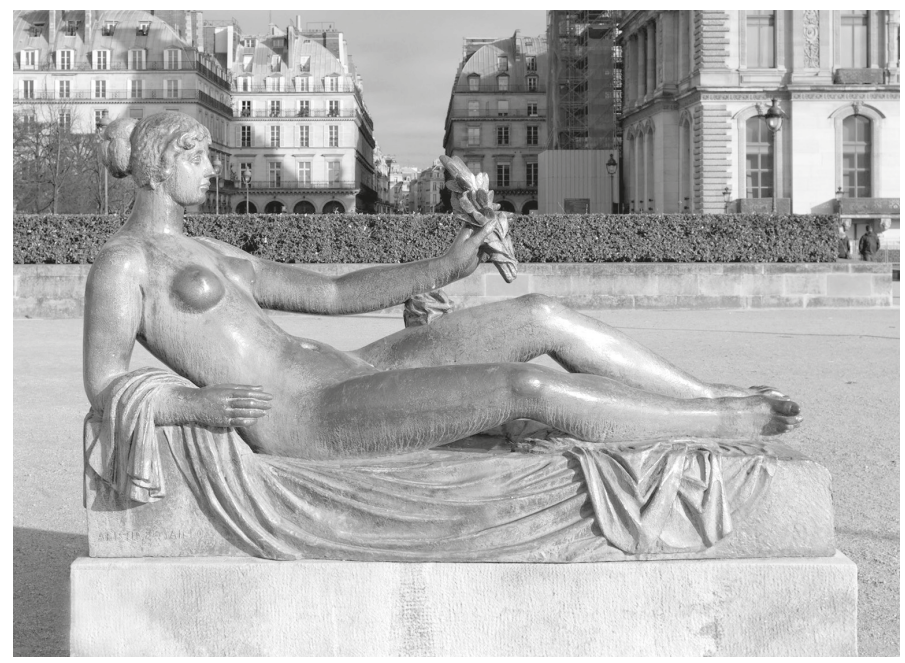

Fig. 5. Aristide Maillol. Monument à Cézanne (L’Hommage à Cézanne). 1912. Jardin des Tuileries, Paris

precisely the symbol of Cezanne's creativity, with an increase in the quality of his painting, which consisted in the formula "to find Poussin in nature". By himself, Poussin, given his role in art, was a symbolic figure, and Cezanne in the interpretation of Maillol becomes a similar symbol.

Interestingly, this work does not exist as a single statue, which can be understood as a monument, but rather as an author's image, whose repetitions can be understood as variable. This proves that Maillol worked, like Antonio Canova, as a painter, who displayed his experience in the context of a three-dimensional work, that is, sculpture. Thus, he created an example for others by the sculptor, but it can also be said that he followed 


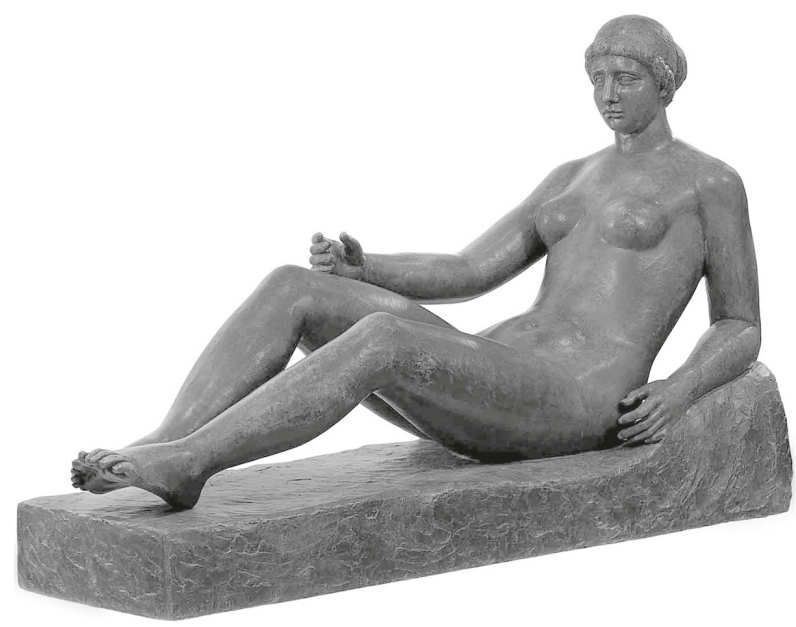

Fig. 6. Aristide Maillol. Reclining Bather (for PortVendres War Memorial). Circa 1922. Private collection

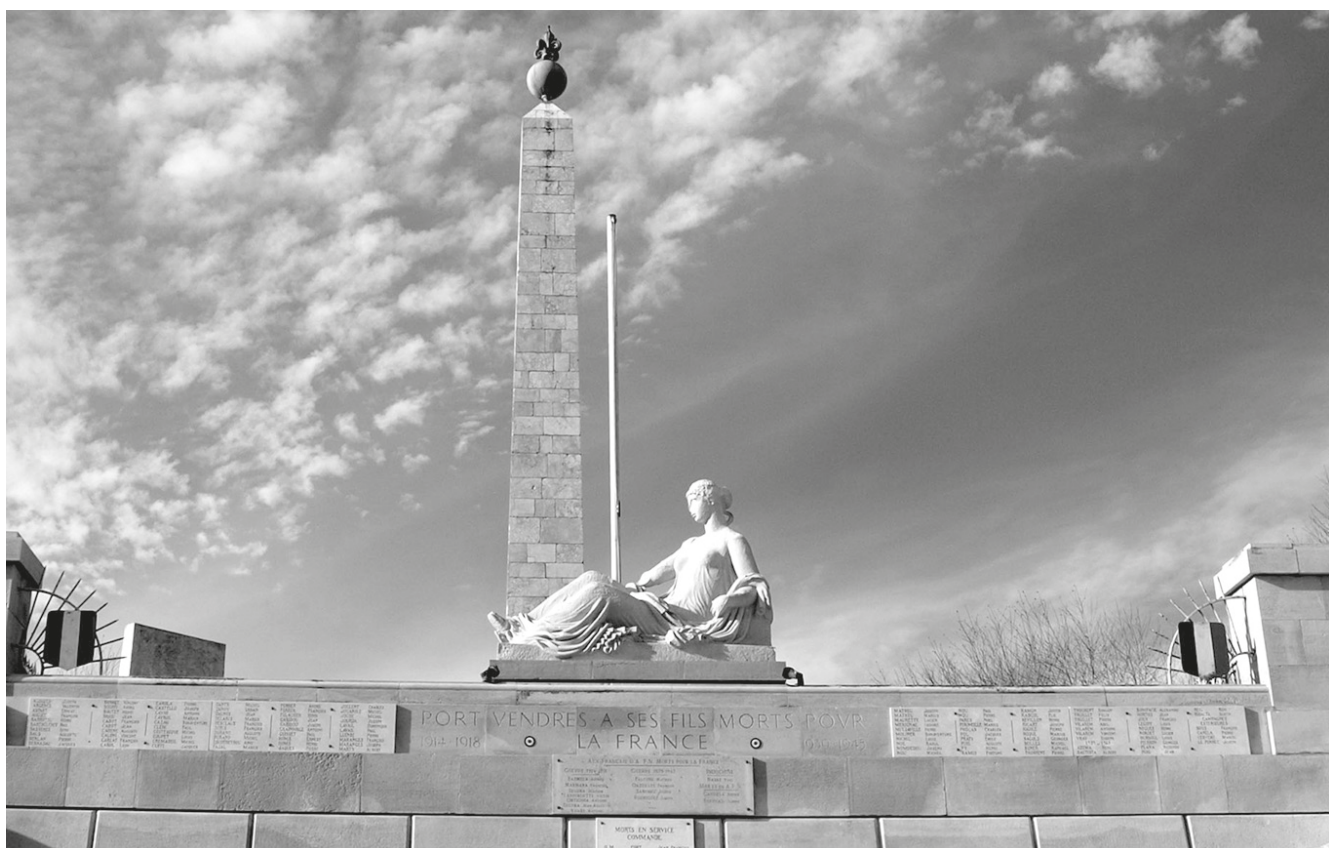

Fig. 7. Aristide Maillol. Port-Vendres War Memorial. 1919-1923. Place de l'Obélisque, Port-Vendres

the principle of classical ideality, where it is the ideal that has objective value, and not its versions.

Therefore, the discoveries of Maillol represent him as an artist who found a balance of modernity and classics. At the same time, it is impossible not to note his significant contribution to the history of monumental sculpture, because his images use generalization techniques, and they express symbolic meaning (fig. 6,7 ). This is akin to the expression 


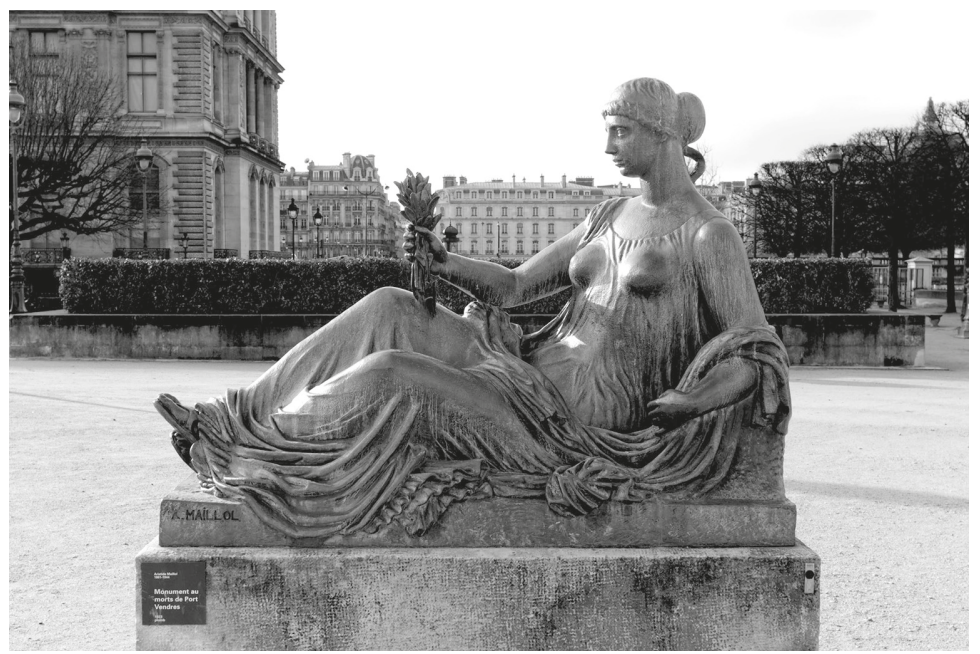

Fig. 8. Aristide Maillol. Port-Vendres War Memorial (variant). 1923. Jardin des Tuileries, Paris

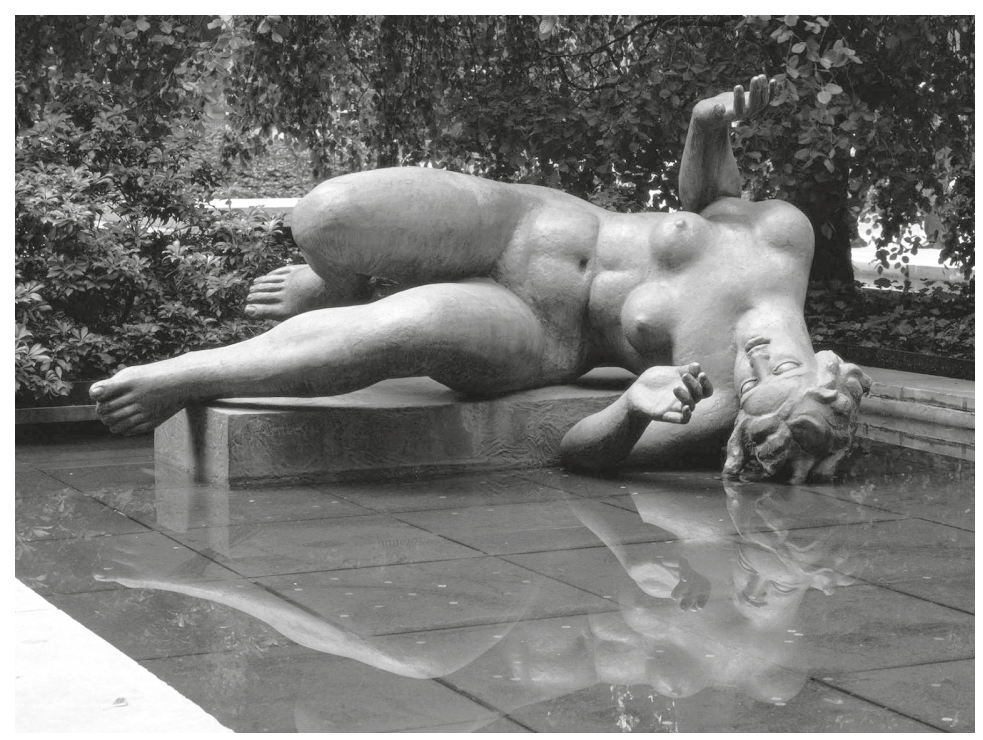

Fig. 9. Aristide Maillol. The River. 1938-1943. Museum of Modern Art, New York

of monumentality in architecture, where there are objective laws that do not negate the significance of creative individuality. This quality of Maillol's sculpture was noted in 1910 by Roger Fry: "He brings sculpture back once more to its true fount and origin, its inspiration and its safest haven - to architecture" [5, p. 32]. The proximity of his sculptures to the landscape also reminds of classical architecture, which can be successfully perceived in the city and in the landscape space, and no one knows where else better.

At the end of his life, Maillol created some similar figurative images (L'Air, La Rivière, 1938, fig. 8, 9), where he strengthened the compositional dynamics. These examples are 
more experimental in character, which adds new qualities to the same canonical, typical, ideal and symbolic image. Also, it is important that one of the most successful ways to exhibit them is associated with the installation in the landscape. This can be treated as a new synthesis, combining the concepts of nature and sculpture, and you can also see the architectural qualities. And this generally refers to the characteristic of the Maillol sculpture.

\section{From Ideal to Archetype: Henry Moore}

For the history of modern sculpture, Henry Moore has a special meaning. An outstanding master of British art of the $20^{\text {th }}$ century, in his works he proved the ability of modernist aesthetics to create forms of a universal nature that can interact with the inner world of any person. His large-format works are the most successful versions of monuments, alternative in form and idea to traditional monuments.

One of the main problems associated with the work of Moore relates to its role in the history of modern sculpture in general, namely its relationship with modernism. On the one hand, the works of Moore are now perceived as a kind of emblem of what is commonly considered the modernist style; they can even be perceived as monuments to the new movement in sculpture. On the other hand, the Moore's method was more traditional than innovative. This is especially true of the late period of his work, when he began to create dozens of large bronze sculptures installed in parks and squares of large cities, sometimes near historic architecture. At the same time, they are completely different from traditional monuments, being in most cases forms that do not have a clear semantic orientation.

In the work of Moore, modernist sculpture took shape in a certain style, although associated with the work of one master, but incorporating the plastic features of many predecessor sculptors. The numerous bronze sculptures he created in the 1950s - 1980s, therefore, should be perceived as monuments dedicated to modern sculpture in general. Moore, being a follower of the founders of the new sculpture, brought their ideas to embodiment in the material, so his monumental "archetypes" are not just large sculptures exhibited in the open air, but monuments to the triumph of modernist idioms in sculpture.

Herbert Read, named Henry Moore's 1929 Reclining Figure (fig. 10) the "archetypal form" where "the symbol is substituted for the concept" [6, p. 227], implied its connection with the universal category of life, with the "vital idea". Thus, he emphasized the importance of the sculptor as a spokesman for a peculiar philosophy of Vitalism, which speaks of the common organic and inorganic world based on the idea of a vital impulse underlying evolution:

“...This particular phase of sculpture has been dominated by the genius of Henry Moore, and an often-quoted statement of his justifies the use of the word vitalism in this connections:

...For me a work must first have a vitality of its own. I do not mean a reflection of the vitality of life, of movement, physical action, frisking, dancing figures and so on, but that a work can have in it a pent-up energy, an intense life of its own, independent of the object it may represent. When a work has this powerful vitality we do not connect the word Beauty with it.

Beauty, in the later Greek or Renaissance sense, is not the aim of my sculpture. 


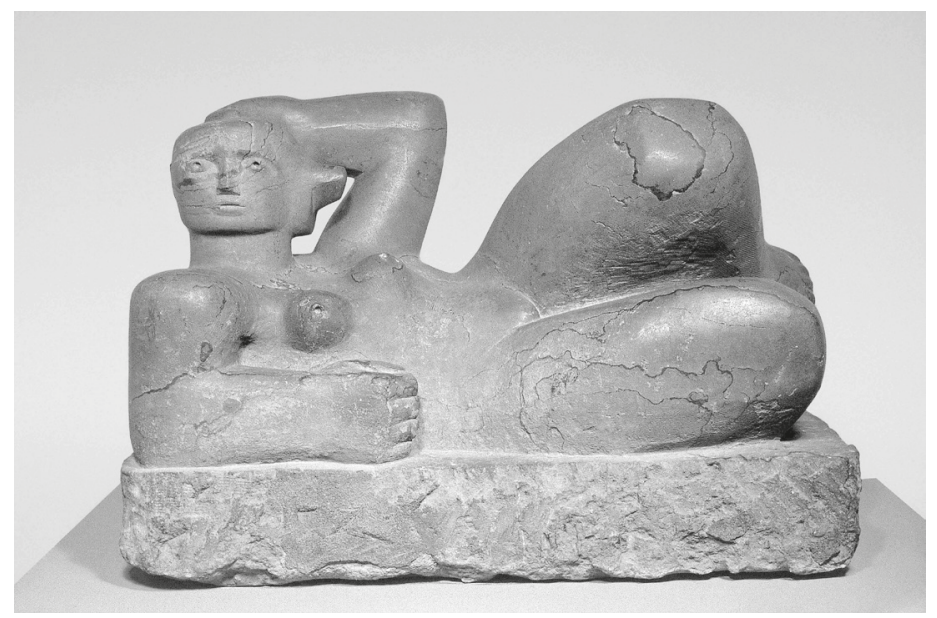
Galleries

Fig. 10. Henry Moore. Reclining Figure. 1929. Leeds Museums and

Between beauty of expression and power of expression there is a difference of function. The first aims at pleasing the senses, the second has a spiritual vitality which for me is more moving and goes deeper than the senses" [3, p. 163].

In addition to Herbert Read's writings [7; 8], in the understanding of which Moore became the leading exponent of the ideas of Vitalism in sculpture, the commentary of the psychoanalyst Erich Neumann [9], a follower of the Jungian tradition, is also characteristic: "He also saw that art is the assertion and manifestation of the universally human, and that experience of this is the first step toward the conscious realization of a unitary culture beyond race, nation, and time. He has glimpsed the oneness of the creative transpersonal powers in humanity itself" [10, p. 97].

Later, a rather in-depth analysis of the root qualities of the Moore sculpture was given in the Rosalind E. Krauss' Passages in modern sculpture (1977):

“...Moore worked with a carver's instincts $<\ldots>$ The extremities of Moore's reclining figures terminate explicitly within the limits of the original mass of material from which the figures were hewn. With outward edges of arms, legs, back, and head conforming to the primitive geometry of the initial block, and the midsection of the figure eroded away to a block-shaped void located at the interior of the figure on an axis perpendicular to the direction of its major mass, the work makes visible a contrapuntal relationship between the shape of the hollow core and the shape of the resultant figure. The sculptural forms appear to have developed from the geometric premise of the hollow core. The result is the sense of voluptuous reciprocity between the form of the container and that of the contained - the exterior mass cradling the void set at its center like a vital organ, and the shape of the void appearing as the key to the developed form of the whole" [11, p. 143]:

"Moore's figures exist in the pregnant moment of rational sequential, casual time. Further, they are shaped as if they came to being at intersecting points in a continuous axial grid. In this sense they seem to be orchestrations of geometrically conceived space" [11, p. 146]. 
Note that the concept of the archetype in relation to the phenomena in art is equally provable and speculative (as is the case with the idea of architectonics). In any case, it is very suitable for characterizing the movement with which Moore was associated for Abstract Vitalism. His sculptures, both figurative and abstract, can be perceived as symbols of modern sculpture as a whole, as if images of its stylistic balance.

At the same time, the "canonicity", inherent in the very nature of Moore's work, brings together his works with the works of archaic sculpture. Thematically, the work of Moore is very "monotonous": the overwhelming majority of his sculptures are called the "Reclining Figure" or "Mother and Child". In them only the forms vary, but the subject-matter remains unchanged. Only a few of his sculptures do not belong to one of these two image types. Perhaps it was the universal and at the same time variable characteristics of the artist's images that allowed Read to name the Reclining Figure the "archetypical form". Moore himself conceptualized this theme; for example, one his statement (1947) can be cited:

"There are three fundamental poses of the human figure. One is standing, the other is seated, and the third is lying down. Now, if you like to carve the human figure in stone, as I do, the standing pose is no good. Stone is not so strong as bone, and the figure will break off at the ankles and topple over. The early Greeks solved this problem by draping the figure and covering the ankles. Later on they supported it against a silly tree trunk.

But with either the seated or the reclining figure one doesn't have this worry. And between them are enough variations to occupy any sculptor for a lifetime. In fact if I were told that from now on I should have stone only for seated figures I should not mind it at all.

But of the three poses, the reclining figure gives the most freedom, compositionally and spatially. The seated figure has to have something to sit on. You can't free it from its pedestal. A reclining figure can recline on any surface. It is free and stable at the same time. It fits in with my belief that sculpture should be permanent, should last for eternity. Also, it has repose. And it suits me - if you know what I mean" [12, p. 218].

Moore found in this image landscape features - and the landscape as such, and the landscape as a genre of art. In this regard, he was close to Maillol, to whom, however, he was rather skeptical. An interesting analysis of the connection of the Moore sculpture to the landscape in painting is provided by David Sylvester:

"The idea that a figure could be a range of mountains was a conscious factor at least as far back as 1930, when Moore wrote of mountains as a sculptural idea and carved the Reclining Woman in green Hornton stone (fig. 11). In the second half of the 1930s he was carving his first figures penetrated with holes and writing of "the mysterious fascination of caves in hillsides and cliffs". Hillsides was the more appropriate thought for the works of the late Fifties and Sixties. In these later pieces the landscape imagery is more deliberately cultivated than before. It is even based at times on landscape paintings - Monet's Etretat pictures (fig. 12), Seurat's Bec du Hoc (fig. 13) - as well as, less consciously, on memories of particular places seen in reality" [13, p. 192].

As for Moore himself, he, for Reclining Figure, argued, for example, about Cezanne, finding in his work the unique qualities of monumentality (again, a parallel with Maillol):

"I want to be quite free of having to find a "reason" for doing the Reclining Figures, and freer still of having to find a "meaning" for them. The vital thing for an artist is to have a subject that allows to try out all kinds of formal ideas - things that he doesn't yet know about for certain but wants to experiment with, as Cezanne did in his "Bathers" series. In my case the reclining figure provides chances of that sort. The subject-matter is given. It's 


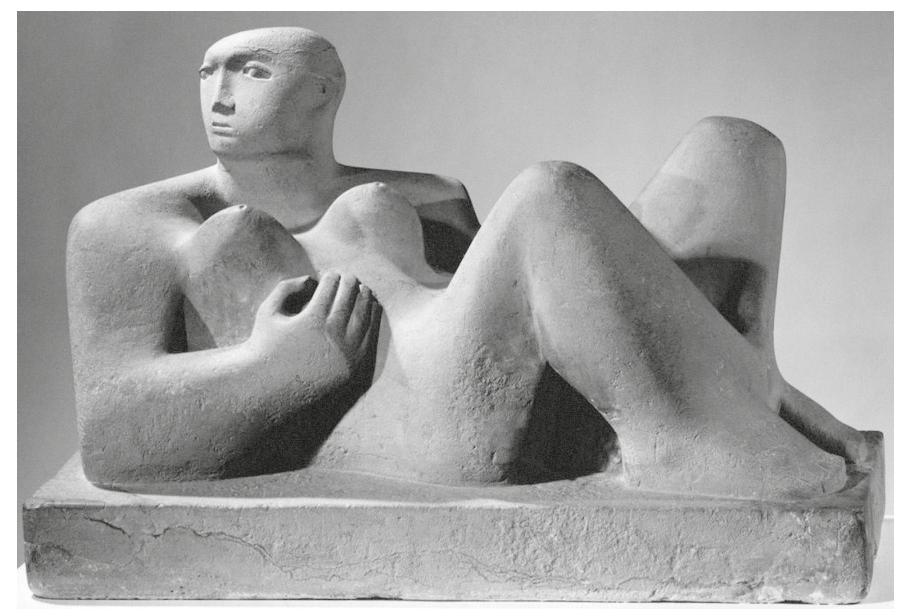

Fig. 11. Henry Moore. Reclining Woman. 1930. National Gallery of Canada, Ottawa

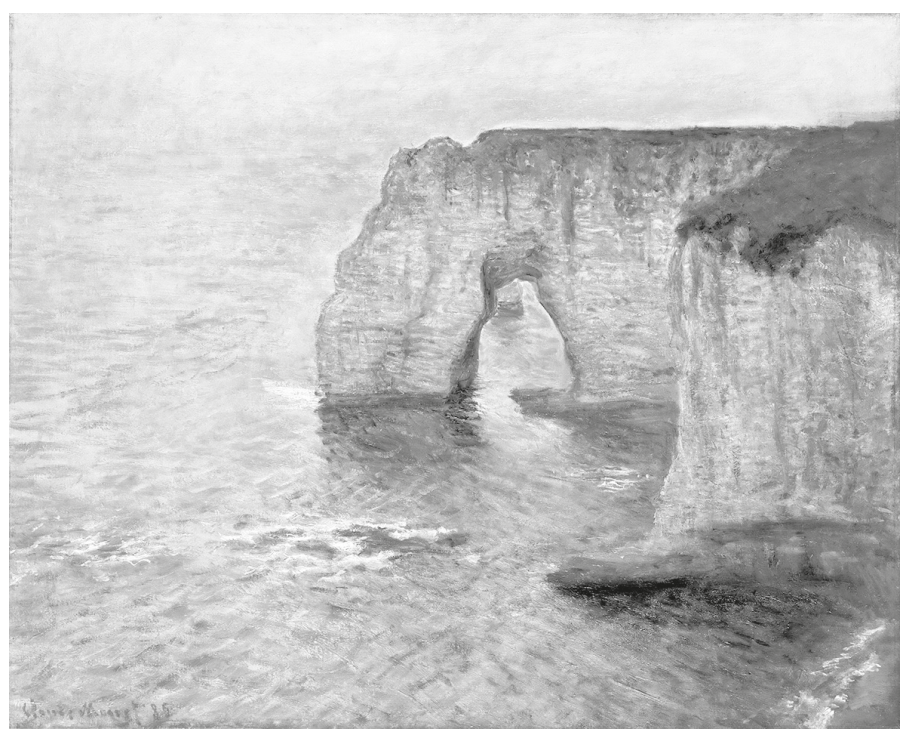

Fig. 12. Claude Monet. Manne-Porte, Etretat. 1885. Philadelphia Museum of Art

settled for you, and you know it and like it, so that within it, within the subject that you've done a dozen times before, you are free to invent a completely new form-idea" [14, p. 212]:

"Sometimes, the impression of seeing something for the first time is immense. A great work, for instance Cezanne's Bathers (fig. 14), the big triangular bathers, will always stand out clearly in my memory. I went to Paris several times when I was a student, but the Cezanne was the big event. He brought painting back from straightforward copying of nature to picture making, into using the mind as well as just taste. I think the photography was playing an important role at this time in that its ability to copy with accuracy freed the painter to explore other ideas. 


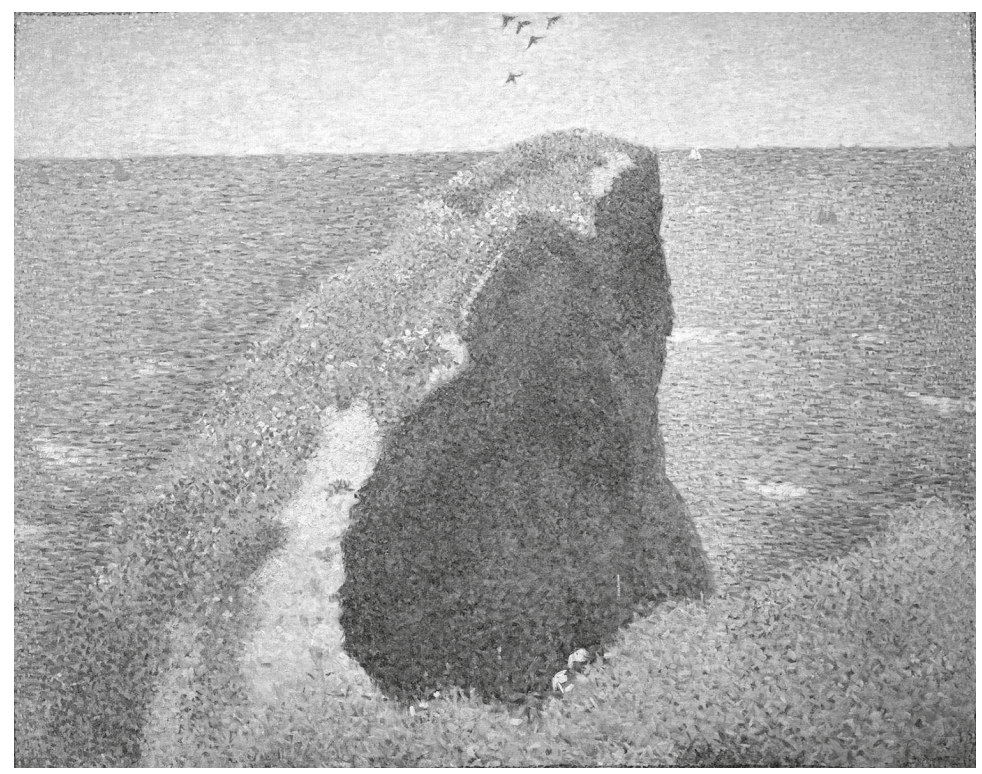

Fig. 13. Georges Seurat. Le Bec du Hoc, Grandcamp. 1885. Tate Gallery, London

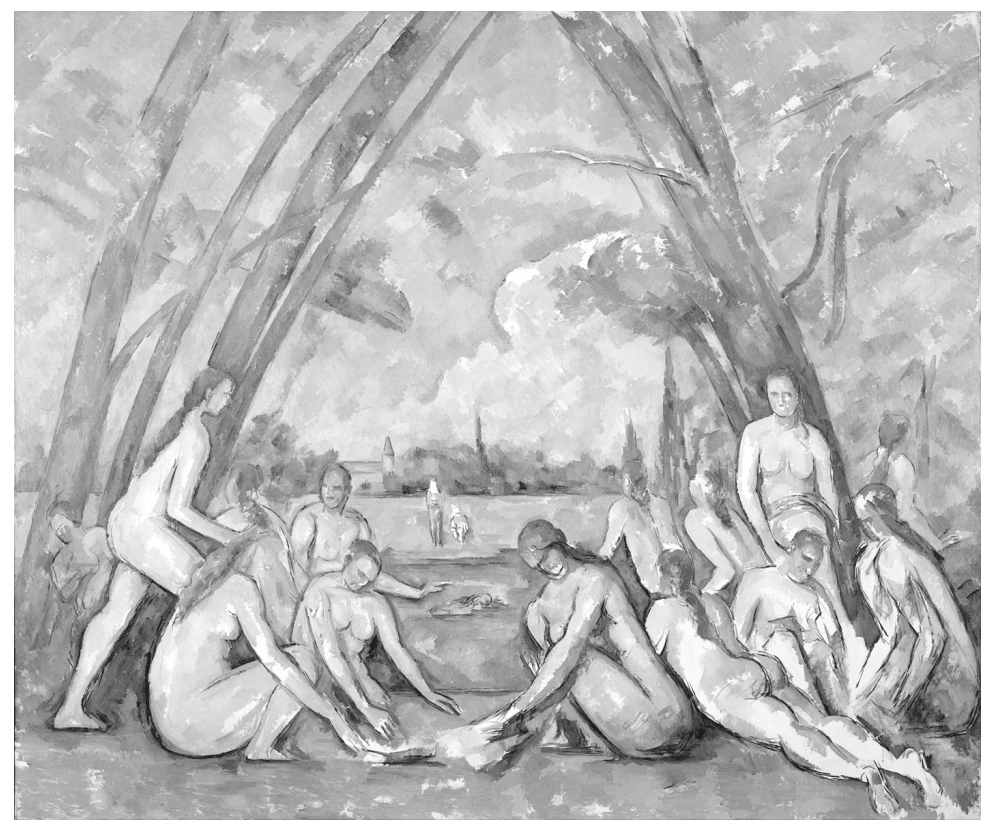

Fig. 14. Paul Cezanne. Les Grandes baigneuses. 1900-1906. Philadelphia Museum of Art 
Cezanne's figures had a monumentality about them that I liked. In his Bathers, the figures were very sculptural in the sense of being big blocks and not a lot of surface detail about them. They are indeed monumental but this doesn't mean fat. It is difficult to explain this difference but you can recognize a kind of strength. This is a quality which you see only if you are sensitive to it. It's to do with the full realization of the three-dimensional form; colour change comes into that too, but not so importantly as human perspective" [15, p. 151].

In the late 1940s - 1950s Moore has gained wide recognition, and with it the possibility of an almost unlimited choice of material for the sculpture and the space for its exhibiting. Many famous works of Moore, from this time on, are large bronze statues representing an alternative to the traditional monument. They stand on the squares, parks and squares of major cities around the world, as if embodying not only the fame of their author, but also recognition of the new sculptural form as a whole. But, in spite of all this, the monumental works of Moore (in particular, his Reclining Figures) also have controversial points that should be emphasized.

Let us quote some well-known authors who talked about Moore's Reclining Figures in terms of their monumental potential.

Edward Lucie-Smith:

"...Moore's figures were not usually expected to symbolize anything but the power of art itself. In this sense he was much freer than his pre-modernist ancestors. Yet there were aspects of post-war work which looked back directly to the nineteenth-century academic tradition which the earliest modernists had vehemently opposed.

Moore's post-war neo-classicism inevitably provoked comparisons with nineteenthcentury artists such as Antonio Canova and Bertel Thorwaldsen. Stylistically these comparisons are misleading, since Moore never practiced the classical style exclusively even when he was most interested in it. One striking thing about his post-war output is its eclecticism" [16, p. 21].

Andrew Causey:

"Moore's sculptures are like national emblems, memorials to Britain's resilience as a nation, gathering together in one symbolic maternal figure the suffering and endurance Moore had drawn in wartime in shelters and down mines. If his figures are in a sense Britannia, they are not triumphalist or emblems of conquest, but suggestive of stoicism and survival. Moore's sophistication lies in his allusiveness and ability to condense meaning so that the wider implications of sculpture, and an arguably conservative cultural attitude, are represented without rhetoric" [17, p.28].

David Hopkins:

"...Moore evoked the archetypes of an island-bound race: rocks eroded by the tides, crustaceans emerging inquisitively from their shells. But if he spoke metaphorically of resilience and native caution, he was capable, at his worst, of blandness.

Moore became the 'acceptable face of modernism' for the postwar British establishment $<\ldots>$ His public sculptures - large, chunky semi-abstractions, cast in bronze, raised on plinth - ironically connoted 'tradition' located in front of Bauhaus-style buildings" $[18$, p. 68].

These three points of view reflect the situation of ambiguous attitude to the large-format works of Moore, in which one can equally see both outstanding examples of modern "monumentalism", and the great artist's compromise with the tastes of the public. Moore himself was an apologist for the "landscape vision" of the sculpture, and it was in harmony with the 
landscape that he understood the expression of the monumental qualities of the statue. Here is a quote from the sculptor's telling about his Memorial Figure (1945-1946, fig. 15):

"I think the figure I carved in 1945 and 1946 in memory of Christopher Martin has found a perfect setting in the grounds of Dartington Hall; there are other parts of those lovely gardens that may have been equally suitable, but it was this setting I had in mind when working on the maquettes. The figure is a memorial to a friend who loved the quiet mellowness of this Devonshire landscape. It is situated at the top of a rise, and when one stands near it and takes in the shape of it in relation to the vista one becomes aware that the raised knee repeats or echoes the gentle roll in the landscape. I wanted it to convey a sense of permanent tranquility, a sense of being from which the stir and fret of human ways had been withdrawn, and all the time I was working on it I was very much aware that I was making a memorial to go into an English scene that is itself a memorial to many generations of men who have engaged in a subtle collaboration with the land. Obviously, it would be out of place in a wilder, more rugged setting" [12, p. 269-70].

Beginning with the post-war period, Moore's sculptures are being built up in urban environment. In 1960s he was commissioned to create a sculpture for the Lincoln Center in New York (fig. 16). The Reclining Figure there is one of his largest works. It is installed on one of the squares included in the architectural complex, inside a reflecting pool, resembling a huge split rock. It should be noted, however, that this sculpture, for all its artistic merit, is still not completely commensurate with the scale of architecture. At a certain point of view, it can even be overlooked. It is not a clear dominant in the square ensemble, although it attracts attention upon relatively close looking. In one of his interviews, Moore, speaking of this work, also formulated his attitude, generally negative, towards such commissions:

"I never seen a person or a piece of sculpture against architecture that I would say can be seen perfectly from every point of view. I just don't know it. When dealing with an architectural situation, I attempt to consider certain things that can go wrong. There is a kind of right size for every such situation. I think that in the Lincoln Center piece its size in relation to the four buildings all around it and to the plaza is just about right. This is the thing I tried to think about. I don't work with architects except on these generalized problems like size. I don't like doing commissions in the sense that I go and look at a site and then think of something. Once I have been asked to consider a certain place where one of my sculptures might possibly be placed, I try to choose something suitable from what I've done or from what I'm about to do. But I don't sit down and try to create something especially for it" [19, p. 176-7].

Moore's attempts on creating new monuments were conducted against the background of a critical discussion about the possibility of the existence of such forms in the context of a modernist idiom. Herbert Read, who already in 1956 in The Art of Sculpture put forward the idea that sculpture finds life as a separate type of artistic expression, only when the idea of a monument falls into decay, adhered to similar views. Read perceived modernism as a phenomenon of arts' separation, while the artistic unity of sculpture and architecture, represented by the form of monumental sculpture, was irretrievably gone. In his opinion, the creation of a monument is currently impossible precisely because of the impossibility of synthesis [20, p. 18].

If it is impossible to find a synthesized image of sculpture and architecture, the work of Moore showed examples when the sculpture, existing in an architectural context, "perceives" 


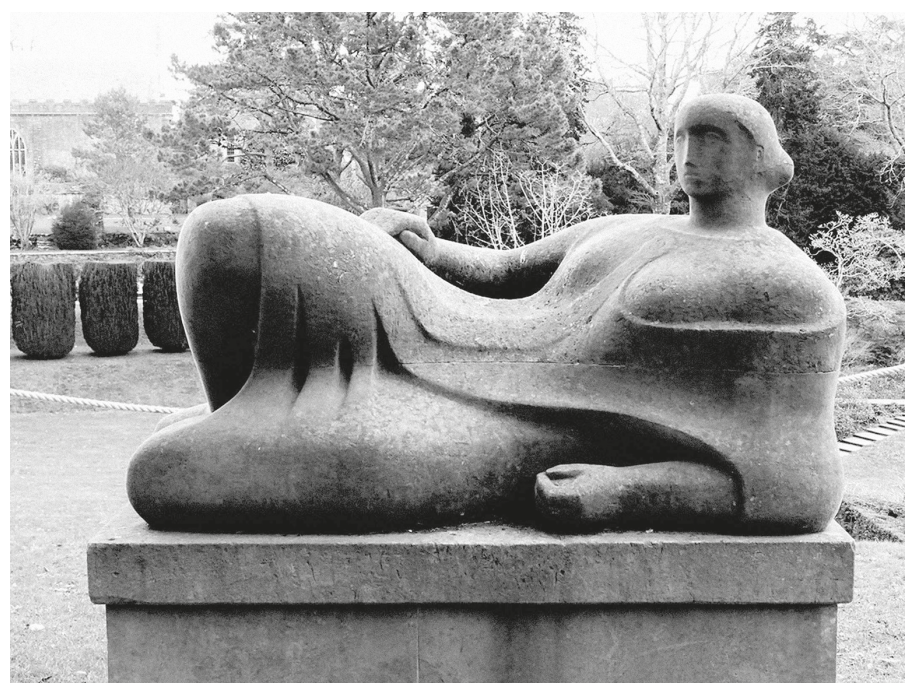

Fig. 15. Henry Moore. Memorial Figure. 1945-1946. Dartington Hall, Devon

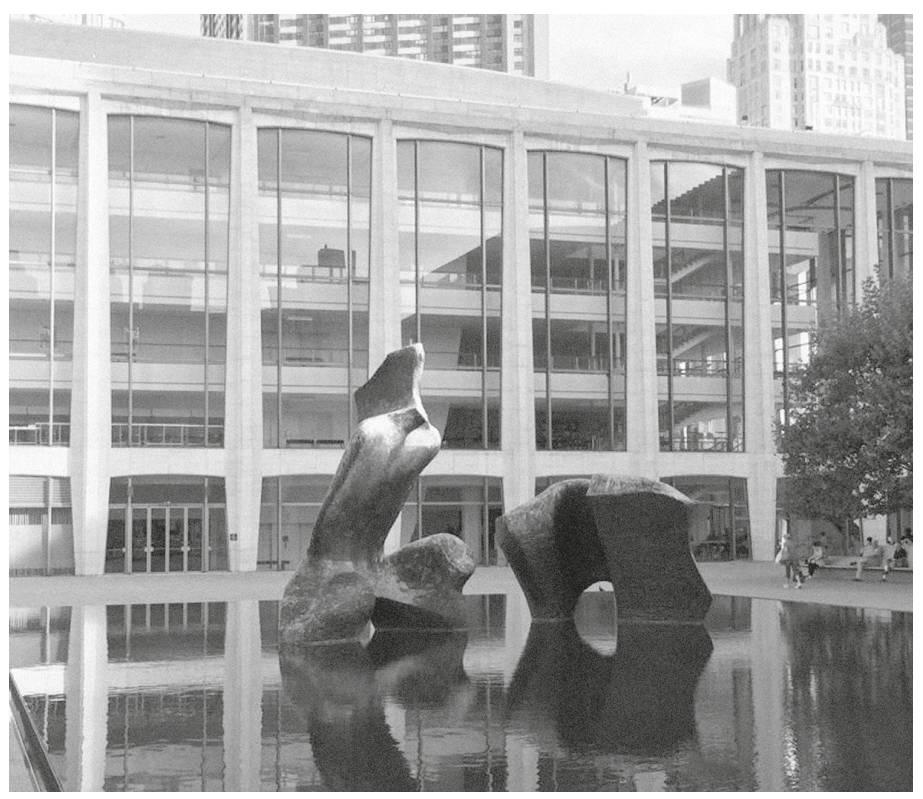

Fig. 16. Henry Moore. Reclining Figure. 1963-1965. Lincoln Center, New York

architecture only as a background, and the architectural environment as an exhibition space. Moore as a whole was very skeptical about the possibility of cooperation between a modern sculptor and a modern architect. In his texts and interviews, he consistently held the point of view that the sculpture should be completely independent. The first example of such statement dates back to 1937: 
"Architecture and sculpture are both dealing with the relationship of masses. In practice architecture is not pure expression but has a functional or utilitarian purpose, which limits it as an art of pure expression. And sculpture, more naturally than architecture, can use organic rhythms. Aesthetically architecture is the abstract relationship of masses. If sculpture is limited to this, then in the field of scale and size architecture has the advantage; but sculpture, not being tied to a functional and utilitarian purpose, can attempt much more freely the exploration of the world of pure form" [21, p. 193].

In addition, the second one - 1978:

"Sculpture is like a human being. Architecture is inhuman" [19, p. 244].

These words clearly reflect the situation in which art appeared between the epochs of the Modernism and Postmodernism, when the previous synthesis was destroyed, but nothing definite came to replace it. And the problems of decorating the architectural space are hardly completely lost relevance. Well, and so on...

In the second half of the $20^{\text {th }}$ century, Moore and some other famous sculptors created a seemingly new tradition of the monument. Was this a genuine alternative? Unlikely. Rather, it is possible to talk about a compromise, about the peculiar monumentalization of the modernist concept of form. And the main role in this situation was played by the individuality of an artist, his talent, energy and activity. The outdoor sculptures of Moore, his large Reclining Figures became in this context the "emblem" of the legitimation of modernism, which itself had turned into a sort of monument by this time. Moore worked with a variable body form, and this really brought his works closer to traditional monuments. Moreover, in his works the author's intonation always prevails, therefore their correlation with any particular subject or function can have only a conditional meaning.

What is the role of tradition in the works of the most famous British sculptor, whose works have long become the emblem of a new plastic form? Was he an innovator or, on the contrary, a traditionalist? In the postwar period, Moore became more and more a lifetime classic, whose name became almost synonymous with the concept of "sculpture of the $20^{\text {th }}$ century". At the same time, he began to undergo critical attacks, the pathos of which gradually increased. The meaning of this criticism was that for Moore, for all his achievements, traditional art was always closer than modern art. He did not accept the new artistic trends that emerged in the 1960s - 1970s, such as Minimalism, his relations with the modernist movement are also not completely unambiguous. What really excited Moore is the "primitive art", filled with ancient magic power, directed, rather, into the dark past than into the future. Also in the postwar period, Moore also showed an interest in classical art in its most traditional understanding, namely, in the art of Greek and Roman antiquity. He began to work a lot in bronze, sometimes in marble, that went against his former neglect of these materials. He often spoke of the importance and value of the classical heritage, as if he were a dedicated traditionalist. After analyzing some important points of the late work of Moore (at least his Reclining Figures from 1950s), we may become closer to understanding his figurative system, and also be able to figure out to what extent a modern artist should or should not turn to artistic classics.

Indeed, unlike traditional monuments of the past, the works of Moore and other prominent masters of our time are lost against the background of architecture and are perceived as a temporary addition to the already established urban situation. The appearance 


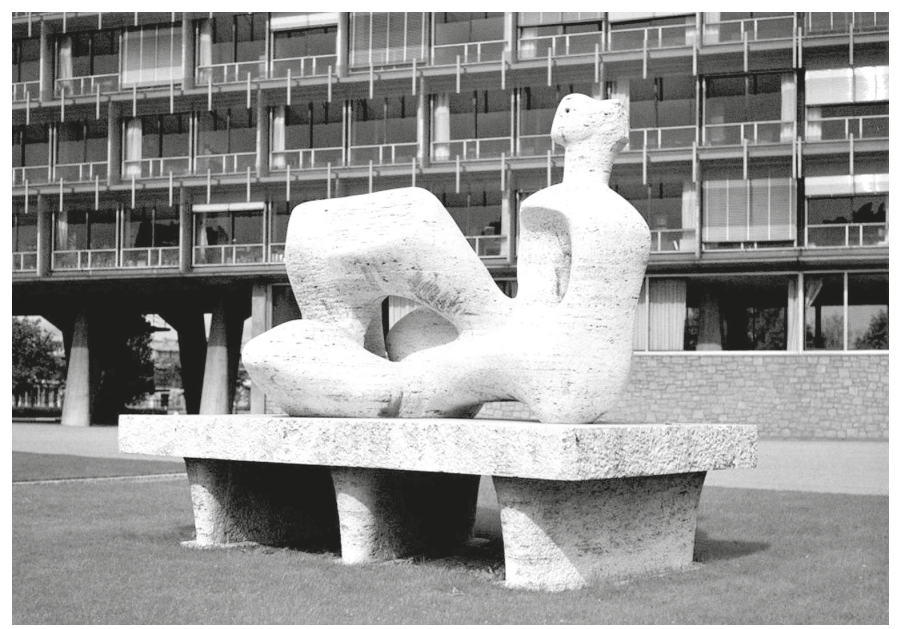

Fig. 17. Henry Moore. UNESCO Reclining Figure. 1957-1958. UNESCO Headquarters, Paris

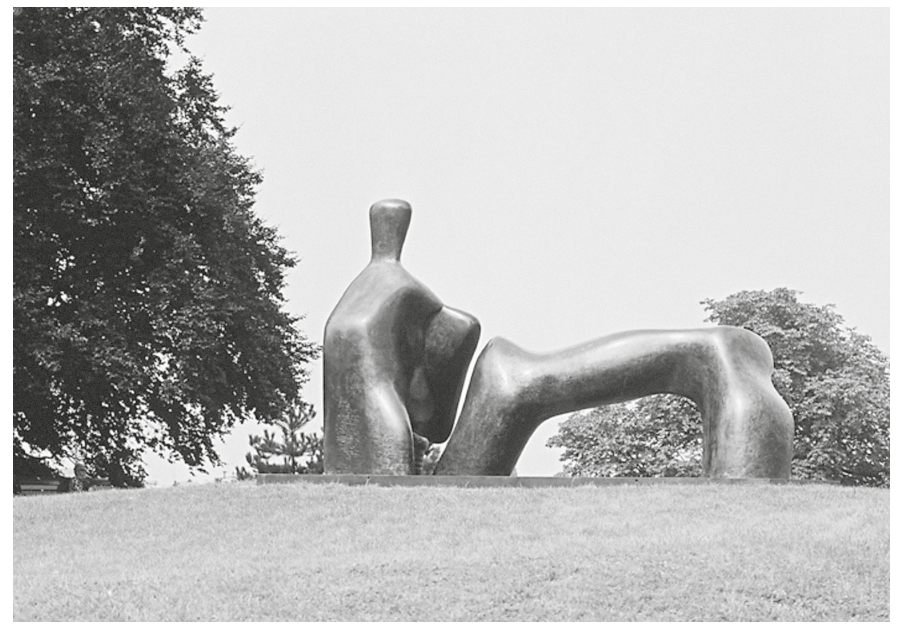

Fig. 18. Henry Moore. Reclining figure, arch leg. 1969-1970. Musée d'Art et d'Histoire, Geneva

of modernist sculpture on the streets and squares contradicts the very spirit of modernism as a movement, directed not towards synthesis, but on the contrary, towards maximum independence of form. The only acceptable space for Moore's monumental works is nature, where they are freed from the forced association with architectural forms (fig. 17, 18).

So, the natural environment is the most organic space for the Moore sculpture, personifying the intention of independence of three-dimensional form in the XX century art. Moore's Reclining Figures, located in the natural environment, have the character of a special type of monument, commensurate with nature - vital force, and defined in this context as a special independent unit among the magnificent forms of the living world. In this sense, it can be said that Moore really proposed an alternative to the traditional monument in the form of a large-format sculpture, abstract as much as possible from 
the possibility of semantic associations and appealing primarily to the idea of pure form. Moore's experience proves that modernist sculpture reveals its best qualities only in ideal conditions - in the emptiness of a spacious exhibition hall or against the backdrop of a majestic expanse of living nature.

The situation with the embodiment of the symbolic and archetypical Reclining Figures demonstrates that individual art strategies, even when they evolve into a version of the new tradition, still prove that entropy trends, reflecting the realities of this period, intensified in the art of the 20th century. Whether the attempts of Maillol and Moore will be perceived as unconditional achievements or will be considered as errors, it is impossible to answer this question now. But it is obvious that both these outstanding sculptors intuitively sought to establish a connection between the present day of art and its past, classics and modernity.

\section{References}

1. Hildebrand, Adolf, von. Das Problem der Form in der bildenden Kunst. Strassburg: Heitz, 1893.

2. Wölfflin, Heinrich. "Adolf Hildebrands 'Problem der Form”. In Kleine Schriften: (1886-1933), Hrsg. von Joseph Gantner, 104-6. Basel: Schwabe, 1946.

3. Curtis, Penelope. Sculpture 1900-1945: After Rodin. Oxford; New York: Oxford University Press, 1999.

4. Wipper, Boris. Introduction to the Historical Study of Art. Moscow: Izobrazitel'noye iskusstvo Publ., 1985. (In Russian)

5. $\quad$ Fry, Roger. “The Sculptures of Maillol”. Burlington Magazine 17, no. 85 (1910): 26-33.

6. Read, Herbert. A Concise History of Modern Sculpture. London: Thames \& Hudson, 1964.

7. Read, Herbert. Icon and Idea: The Function of Art in the Development of Human Consciousness. Cambridge MA: Harvard University Press, 1955.

8. Read, Herbert. Henry Moore: A Study of His Life and Work. New York: Frederick A. Praeger, 1966.

9. Martin, Tim. "Erich Neumann on Henry Moore: Public Sculpture and the Collective Unconscious". In Henry Moore: Sculptural Process and Public Identity. London: Tate Research Publication, 2015. Accessed March 08, 2019. https://www.tate.org.uk/art/research-publications/henry-moore/tim-martinerich-neumann-on-henry-moore-public-sculpture-and-the-collective-unconscious-r1151316.

10. Neumann, Erich. The Archetypal World of Henry Moore. New York: Pantheon Books, 1959.

11. Krauss, Rosalind E. Passages in Modern Sculpture. New York: The Viking Press, 1977.

12. Wilkinson, Alan, ed. Henry Moore: Writings and Conversations. Berkeley: University of California Press, 2002.

13. Sylvester, David. About Modern Art: Critical Essays, 1948-96. London: Chatto \& Windus, 1996.

14. Russell, John. Henry Moore. London: Allen Lane; The Penguin Press, 1968.

15. Moor, Henry, words by, and John Hedgecoe, phot. and ed. Henry Spencer Moore. New York: Simon and Schuster, 1968.

16. Lucie-Smith, Edward. Sculpture Since 1945. London: Phaidon, 1987.

17. Causey, Andrew. Sculpture Since 1945. Oxford; New York: Oxford University Press, 1998.

18. Hopkins, David. After Modern Art. 1945-2000. Oxford; New York: Oxford University Press, 2000.

19. Seldis, Henry J. Henry Moore in America. London: Praeger, 1973.

20. Read, Herbert. The Art of Sculpture. London: Faber \& Faber, 1956.

21. Martin, John Leslie, Ben Nicholson, and Naum Gabo, eds. Circle: International Survey of Contemporary Art. London: Faber and Faber, 1937.

Received: April 02, 2019

Accepted: May 28, 2019

Author's information:

Alexander O.Kotlomanov - PhD, Associate Professor; kotlomanov@yandex.ru 